Ольга ШЛЕМКО

\title{
ДРАМА Г. ХОТКЕВИЧА «ДОВБУШ» У РАКУРСІ СУЧАСНИХ ДОСЛІДЖЕНЬ
}

У статті подано історію створення Г. Хоткевичем драми «Довбуш», ї̈ проблематику, жанрово-стильові особливості. Здійснено аналіз публікаиій тексту п'єси «Довбуш» та критичний огляд ї̈ сучасних досліджень.

Ключові слова: Довбуш, драма, жанр, Хоткевич, Гучульський театр, гуиульська говірка.

В статье представлена история создания Г. Хоткевичем драмы «Довбушџ, ее проблематика, жанрово-стилевые особенности. Проведен анализ публикаций текста пьесы «Довбуш» и критический обзор ее современных исследований.

Ключевые слова: Довбуш, драма, жанр, Хоткевич, Гуиульский театр, гуиульский говор.

In the article the history of G. Khotkevych's creating of drama «Dovbush», its issues, genre and style peculiarities are highlighted. The text of the play «Dovbush» and the critical review of the modern researches of it are analysed.

Keywords: Dovbush, drama, G. Khotkevych, Huzul theatre, Huzul dialect.

Необхідність відновлення історичної пам'яті українського народу, створення пантеону національних героїв як чинника консолідації суспільства та формування національної ідентичності, вимагає цілеспрямованої державної політики, залучення фахівців різних галузей науки, митців, подолання дуалізму громадської думки, регіональних уподобань, маніпулятивних практик впливу на суспільну свідомість. Важливу роль у цьому тривалому процесі відновлення історичної пам'яті має відігравати також і театральне мистецтво.

Актуальність статті полягає у тому, що на тлі викликів XXI століття, що постали перед Україною, яка втратила частину своєї території і перебуває у стані неоголошеної війни, суспільної дискусії щодо пошуку національних героїв, які могли б об'єднати всі регіони України, залишається невикористаним значний драматургічний доробок Г. Хоткевича, пов'язаний з відображенням образу народного героя Олекси Довбуша, який діяв у 30 40-х роках XVIII ст., героїчної боротьби опришківства як соціального феномену.

Видатного українського письменника Г. Хоткевича ріднило 3 Довбушем почуття власної гідності, гостре почуття справедливості, пошуки правди. Вони навіть мали однакову фізичну ваду — «на ніженьку налягали» і обоє загинули за правду. Недарма він написав про Довбуша дві драми, повість, оповідання, спорудивши таким чином Довбушеві нетлінний літературний пам'ятник.

У своїх публікаціях висвітленню п'єс Г. Хоткевича на гуцульську тематику, зокрема, драми «Довбуш» частково торкалися П. Арсенич, Т. Бикова, П. Будівський, Л. Вдовиченко, І. Волицька, Р. Кирчів, Ф. Погребенник， В. Стефюк， С. Чарнецький. У дисертаційному дослідженні (2004) авторки цієї статті системно досліджено різні аспекти діяльності Гуцульського театру, в тому числі проаналізовано, на підставі ознайомлення 3 архівними рукописами, всі гуцульські п’єси, а згаданий театр постає як мистецький та етносоціокультурний феномен світового масштабу. Аналіз драми «Довбуш» Г. Хоткевича здійснено і в інших публікаціях авторки.

Мета статті полягає у визначенні проблематики та жанрово-стилістичних особливостей п'єс Г. Хоткевича про Олексу Довбуша, з'ясуванні історії їх написання, сценічного втілення та сучасного дослідження.

Серед концептуальних засад Гуцульського театру - забезпечення принципу сценічного тринома: гуцульський актор - гуцульська говірка - 
гуцульський репертуар. Для Гуцульського театру репертуар був не лише візитною карткою, а й ідейним стрижнем і своєрідною програмою дій. Слід враховувати, що Г. Хоткевич виступав у ролі першопроходця, творячи, по суті, новітню гуцульську драму. Різнобарвна жанрова палітра гуцульських п'єс Г. Хоткевича поєднала в собі соціально-історичні драми «Антін Ревізорчук» («Верховинці») i «Довбуш», фантастичну драму «Непросте», містеріальну драму «Гуцульський рік», фантастичну казкову драму «Прахтикований жовнір».

Публікацію гуцульських п’єс Г.Хоткевича розпочали П. Будівський та Л.Будівська, вмістивши в журналі «Бахмутський шлях» (1997, № 3-4) п’єсу «Довбуш». Вони стверджують, що відновив цей текст наймолодший актор Гуцульського театру Г. Гулейчук, хоча такого актора в цьому театрі ніколи не було. Судячи з контексту, це був Іван Ілійчук, який передав відновлений текст п'єси Платоніді Хоткевич. Натомість вона, незадовго до своєї смерті у 1976 р., передала рукопис п'єси А. Ф. Мельничук, від якої він вже потрапив до Будівських. Останні вважають, що відновлена п'єса - «це покращена редакція твору, оскільки відомо, що актори Гуцульського театру дещо правили текст — п’єса вийшла художньо-стрункішою, відшліфованішою, і драматург-режисер Г. Хоткевич щиро 3 цього радів» [2, 75]. Тобто, навіть не тримаючи в руках оригінального тексту п’єси, вони впевнені, що у відновленій редакції текст покращений, а також переконані, що Г. Хоткевич бачив цю редакцію п'єси і навіть радів, хоча це абсолютно бездоказово. Більше того, вони вважають, що рукопис оригінальної драми загинув, а тому його було відновлено у 1934 р. [2, 75], тобто більше ніж через двадцять років після припинення діяльності Гуцульського театру. Насправді ж, різні варіанти й редакції драми «Довбуш» зберігаються в архівних установах України і Російської Федерації.

Порівняльний аналіз оригінальної драми «Довбуш» і опублікованої однойменної драми свідчить про розбіжності у тексті, а також про те, що остання в жодному разі не є покращеною редакцією, а лише спрощеним іï варіантом. Автори-упорядники зізнаються, що «у пропонованій драмі Г.Хоткевича “Довбуш” чуть модифікували гуцульський діалект загальнонародною лексикою» $[18,76]$. Пояснюючи окремі лексеми гуцульського говору, вони перекладають «ковбок» як «пень» $[18$, 48], хоча треба як «колода» або ж загальновідоме слово «ліпше» чомусь вважають гуцульським, а тому перекладають і його. Перекручено слова матері, яка, звертаючись до своїх синів Олекси та Івана Довбушів, приказує: «Ягнятка мої, соколики мої!» $[18,50]$. Насправді ж вона каже: «Синєтка (синочки - О. Ш.) мої, соколики мої!» Не будемо зупинятися на інших неточностях у тексті п'єси та коментарях. В іншій публікації Л. Будівського, що грунтується на результатах його дисертаційного дослідження, аналіз опублікованої п’єси «Довбуш» подано ширше [3, 327-346].

Ще одну публікацію гуцульських п’єс Г. Хоткевича здійснили М. Дзурак, Р. Марків, А. Вовчак, упорядкувавши та підготувавши до друку текст книжки «Неопубліковані гуцульські п’єси» (2005), де вміщено шість п'єс. Однак це видання породило чимало запитань. У примітках професор І. Денисюк несподівано робить відкриття, що першою оригінальною п’єсою Г.Хоткевича була «“Довбуш": повість драматична у 7 сценах». До того ж він уточнює, що «це перша редакція історичної драми про Довбуша» $[5,300]$, хоча насправді вона була написана вже за радянських часів. Далі вчений розмірковує: «3 усією очевидністю у процесі сценічної апробації автор удосконалював текст цієї п'єси, зокрема робив композиційні зміни. У результаті скорочення замість семи “сцен” вийшло шість “дій”» $[5,300]$. Тож він робить такий хибний висновок : «По суті, постала нова редакція твору, яка має самостійне значення й заслуговує на опублікування» $[5,300]$. У зв' язку з цим виникає запитання: а чому ж тоді не мають права на публікацію оригінальні тексти драми «Довбуш», що зберігаються в різних архівних установах. Відповідь очевидна. Нi І.Денисюк, ні автори-упорядники згаданої книжки про їхне існування просто не знали. Зі слів професора довідуємось, що, окрім «Довбуша», текст ще однієї п'єси так само опублікований за рукописом, що зберігався у когось 3 артистів Гуцульського театру. Це, безперечно, знижує рівень достовірності текстів опублікованих п'єс.

Виявляється, що можна приступати до публікації п'єс Г. Хоткевича без належної пошукової роботи, з'ясування історії їх написання, без порівняльного текстологічного аналізу різних варіантів. Зрештою, вчений сам того не підозрюючи, підтверджує факт скоєного фальсифікату: «Друкуємо “Довбуша" за рукописною копією п'єси 3 якогось раніше тексту, що iï виготовив один з артистів Гуцульського театру. Переписавши п'єсу у грубому зошиті, він зазначив: Красноїлля, дня 21.XII.1941 р. Сенітович» [5, 300].

Порівняльний аналіз текстів п'єси «Довбуш», опублікованих у журналі «Бахмутський шлях» (1997, № 3-4) і книжці «Неопубліковані гуцульські п'єси» (2005) свідчить про те, що це фактично ідентичні редакції, незначні відмінності в яких ви- 
никли внаслідок коректив, внесених їхніми переписувачами та авторами-упорядниками. Натомість порівняльний аналіз згаданих опублікованих текстів п'єси «Довбуш» 3 iї оригінальним текстом виявив у них чимало розбіжностей. Певною мірою можна вважати опубліковані тексти спрощеним i скорегованим варіантом оригінального тексту.

Слід відрізняти текст п'єси та іï сценічну інтерпретацію. В процесі постановки п'єси, зважаючи на низку обставин, до ії тексту можуть бути внесені деякі зміни. Однак це не означає, що автор одразу ж вносить зміни до оригінального тексту п'єси. Г. Хоткевич дуже відповідально ставився до своїх творів, до вживання гуцульської говірки, кожне слово якої було ним відчуте і осмислене. Тож приписувати йому перероблений кимось текст неприпустимо. Очевидно, що розуміла це й дружина письменника Платоніда Хоткевич, а тому й не передала в архів відновлений текст п'єси «Довбуш». У червні 1941 р., ще до початку війни, вона передала деяку частину архіву Г. Хоткевича до Інституту літератури Академії наук УРСР, а в середині 1943 р., в умовах воєнного лихоліття, вивезла значну частину архіву до Львова. Звільнившись на початку 1956 р. після десятирічного перебування в радянських концтаборах та засланні, вона деякий час мешкала, як і колись Г. Хоткевич, у гуцульській Криворівні, де очолювала Літературно-меморіальний музей І. Франка. Саме завдяки подвижницькій праці цієї мужньої жінки ми маємо можливість ознайомитись 3 оригінальною драмою «Довбуш» та іншими гуцульськими п'єсами. Отож сучасним науковцям слід поцінувати працю людини, яка зуміла зберегти безцінну спадщину Г. Хоткевича.

Проте згадані сумнівні джерела вже використовуються для написання наукових статей та дисертаційних досліджень. При цьому нехтується введена в науковий обіг інформація про оригінальні рукописні п'єси Г. Хоткевича [22], що зберігаються в архівних установах. Так, дослідниця Л. Вдовиченко, аналізуючи у своїх наукових статтях [4] та дисертації п’єсу «Довбуш», цілком покладається на текст п’єси, опублікований у «Бахмутському шляху». Вона навіть не вказує, який саме варіант п'єси розглядає: на 5 дій чи 7 сцен, оскільки не підозрює про існування ще якихось варіантів, окрім згаданого. Інша дослідниця Т. Бикова, намагаючись розкрити у своєму дисертаційному дослідженні культурологічні коди творів про Гуцульщину перших десятиліть XX ст., аналізує, зокрема, й драму «Довбуш» Г. Хоткевича [1], вміщену в «Неопублікованих гуцульських п’єсах».
Раритетність Гуцульського театру обумовлена значною мірою його оригінальним гуцульським стилем, витвореним на народному грунті талантом Г. Хоткевича та його однодумців. Важливим стилеутворюючим фактором є гуцульська говірка. Бездоганно відтворити зафіксовану у драматичних творах говірку було під силу лише гуцульським акторам, які з молоком матері ввібрали в себе мелодику, ритми, інтонації рідної мови. Мова персонажів $є$ також важливим засобом характеристики цих персонажів. Корінні гуцули послуговуються у драмі «Довбуш» виключно гуцульською говіркою, що відображає особливості їх характеру, світогляду, моральних засад. Натомість мова не гуцулів більше тяжіє до української літературної мови. Так, пересипана польськими словами, мова полковника Пшилуського надає цьому персонажеві характерних національних ознак.

Невисока оцінка деякими сучасниками Гуцульського театру, зокрема, С. Чарнецьким, гуцульських п'єс Г.Хоткевича пояснюється, на нашу думку, насамперед оманливою простотою цих творів, які не вписувалися в «прокрустове ложе» класичної європейської i, зокрема, української драматургії. Потужна енергетика гуцульських п’єс грунтується насамперед на народній традиції, яка сягає тисячоліть і виявляється цілком лише під час сценічного втілення. Тому оцінка постановок п'єс була вищою, аніж самих п’єс. Водночас $\epsilon$ й інші думки щодо художнього рівня гуцульських п'єс. Так, вже в радянські часи Р. Кирчів стверджував, що «драма “Довбуш” характеризується, перш за все, чіткістю сюжету і послідовним розгортанням драматургічної дії $<\ldots>$ В драмі добре показані ті причини, які приводять Довбуша й інших до опришківства» $[6,145]$.

За жанровою ознакою п'єсу «Довбуш» можна визначити як соціально-історичну драму. Відомо про наявність семи недатованих рукописів п'єси «Довбуш», шість 3 яких зберігаються в Україні, а один - у Російській Федерації. Насправді, коли спробувати класифікувати ці примірники, то виявиться, що $\epsilon$ фактично два варіанти драми: перший - у 5 діях і 6 картинах, другий - у 7 сценах. Відмінність між цими варіантами драми не лише у їхній структурі, а й у розвитку сюжетних ліній та побудові конфлікту. Хоча у всіх рукописних примірниках п'єси, окрім одного, вживається назва «Добуш», для зручності будемо послуговуватись лише назвою «Довбуш».

Аналіз деяких архівних документів дає підстави стверджувати, що п'єса «Довбуш» у 5 діях була написана у 1908 р. Перша рукописна редак- 
ція цієї п’єси зберігається у фонді Г. Хоткевича в Центральному державному історичному архіві України у Львові (далі - ЦДІА України у Львові) [13]. У цьому примірнику відсутні початок першої і кінець п’ятої дій. Зважаючи на численні виправлення у тексті, його можна вважати чернеткою або першою редакцією першого варіанта драми «Довбуш».

Друга рукописна редакція п’єси «Довбуш» у 5 діях, що визначена як «сценічний образ», зберігається у відділі рукописів Інституту літератури ім. Т. Г. Шевченка НАН України [11]. Письменник 1909 р. надіслав цю п’єсу до російської цензури, сподіваючись виставляти іiі під час гастролей Наддніпрянською Україною. Однак, згідно з листом Канцелярії Головного управління у справах друку Міністерства внутрішніх справ Російської імперії від 8.06.1909 р. на ім'я Г. Хоткевича, п’єсу «Довбуш» було визнано «неудобною к представлению на сцене» [7].

Третя рукописна редакція п'єси «Довбуш» у 5 діях, ідентична другій редакції, зберігається у Санкт-Петербурзькій державній театральній бібліотеці [12]. Безжальною рукою цензора М. Алферакі на титульній сторінці цього примірника п'єси виведено: «К представлению признано неудобным. С.-Петербург. 3 июня 1909 г.». У своєму відгуку згаданий цензор, зокрема, відзначив, що «Алекса Добуш, атаман шайки разбойников прославляется, несмотря на все свои зверства и злодеяния, как народный герой, защитник униженных и оскорбленных, мститель за народные страдания и поборник украинской вольности» [21].

Після «копіткої» праці цензора текст п'єси рясніє від численних підкреслень та перекреслень червоним олівцем окремих слів і цілих речень. У відповідь на дії російської цензури Г. Хоткевич того ж таки 1909 р. в статті, опублікованій в газеті «Діло», піддав різкій критиці методи розправи цензури $з$ його п’єсою «Довбуш». «Незважаючи на те, що закон забороняє цензорові викреслювати окремі слова і речення, - зазначає Г. Хоткевич, - він викреслив репліки, де говориться, чому на світі $є$ багаті й бідні, згадуються "панські пси”, “піп”, “Бог”» [20]. Лише 1913 р. Г. Хоткевичу врешті вдалося отримати дозвіл російської цензури на постановку п’єси «Довбуш».

Четверта рукописна редакція п’єси «Довбуш» у 5 діях зберігається у фонді Г. Хоткевича в ЦДІА України у Львові [17]. На нашу думку, саме ця редакція п'єси під жанровим підзаголовком: «Історичне представлення в 5 діях, 6 картинах, діється в XVIII ст.», була поставлена в Гуцульському теа- трі. Прем'єра вистави відбулась у кінці листопада або на початку грудня 1911 р. у Косові.

При порівняльному текстологічному аналізові згаданих чотирьох редакцій п'єси «Довбуш» у 5 діях виявлено незначні різночитання. Якщо, наприклад, у четвертому примірнику діє ксьондз, то у перших трьох - священик, що можна пояснити адаптацією тексту цих примірників до цензурних вимог Російської імперії.

Існує також три, майже ідентичних, примірники другого варіанта п'єси «Довбуш» у 7 сценах. Перша рукописна редакція цієї п'єси зберігається в ЦДІА у Львові [16] 3 написом на титульній сторінці: «Повість драматична у 7 сценах». Те, що саме ця редакція є першою, свідчать деякі авторські виправлення у тексті, враховані у наступних редакціях. У цьому ж архіві зберігається друга машинописна редакція п'єси [15]. Третя рукописна редакція п'єси «Довбуш» у 7 сценах, ідентична двом попереднім, зберігається у відділі рукописних фондів Державного музею театрального, музичного та кіномистецтва України [14]. Платоніда Хоткевич, яка власноруч переписала текст цієї п'єси, очевидно, з рукописного примірника, що зберігається в ЦДІА у Львові, зазначила на початку п'єси, що другий варіант був перероблений автором для постановки в театрі «Березіль» режисером Л. Курбасом у 1923-1928 pp. [14].

Один із дослідників Гуцульського театру В. Стеф'юк припускається грубої помилки, стверджуючи, що Г. Хоткевич поставив у Гуцульському театрі саме драму «Довбуш» у 7 сценах. Аналізуючи цю драму, дослідник зазначає, що «в першій дії глядач стає свідком кривавої Довбушевої розправи, чує його палкий заклик до народу» $[9,68]$. Проте факти свідчать, що глядач був позбавлений можливості почути цей заклик, оскільки згадана п'єса так і не була виставлена.

Знаменно, що першою п'єсою Г. Хоткевича 3 гуцульського життя була саме драма «Довбуш», у якій ватажок опришків Олекса Довбуш став символом боротьби гуцулів проти польської шляхти, різного роду орендарів та лихварів. Драма «Довбуш» 3-поміж інших п'єс на гуцульську тематику була «найслабша річ», — вважав Г. Хоткевич, хоча мав 3 нею «найбільше мороки. Це був чисто історичний Довбуш, без найменшої вигадки, і в тому було його слабе місце» $[19,552]$. Така сувора критика автором свого твору свідчить насамперед про високий рівень вимогливості до драми, яка мала б стати візитною карткою театру.

Сюжет п’єси грунтується на численних переказах, легендах та народних піснях про славного 
ватажка опришків, зокрема, на відомій пісні «Ой, попід гай зелененький ходить Довбуш молоденький». Конфлікт у драмі «Довбуш» є головною рушійною силою розвитку дії і основним засобом розкриття характерів персонажів. Тип конфлікту - антагоністичний, оскільки носить непримиренний характер. Соціальний конфлікт має водночас національне забарвлення, оскільки основні суб'єкти конфлікту є представниками Речі Посполитої, що пригноблювала населення західноукраїнських земель. У Довбуша конфлікт не лише зовнішній, а й внутрішній - морально-психологічний: роздуми над своїми вчинками.

У першій дії п’єси міститься експозиція i зав'язка. В Олекси, якому притаманне гостре відчуття власної гідності та справедливості, визріває протест проти насильства над гуцулами. Прийнявши рішення йти з братом Іваном в опришки, Олекса каже: «А ци так ліпше терпіти, шо пан над тобов газда, пидстароста над тобов газда, окоман над тобов газда та ше й жид над тобов газда! <..> А люде шо? Єк вівці тоті! Сами шию пидстав'єют, сами си в єрмо пхают. Ой шє не так нас обсєдут, шє не так нас приверчут, йк мемо мовчєти!» $[17,2$ зв.]

Відома історична постать Дідушко, якому присвячена друга дія, постає у драмі як жорстокий і бездушний дідич, який вихваляється, що зловить ватажка опришків. У його особі Довбуш має сильного супротивника, що підсилює лінію конфлікту. Сцену вбивства Довбушем Дідушка драматург відтворив майже 3 документальною достовірністю. Це свідчить про його можливу обізнаність 3 деякими архівними документами. Водночас Дідушковому синові Довбуш дарує життя, наказавши навіки забути про помсту.

У третій дії характер конфлікту переміщується в дещо іншу площину - особистісну. Цей конфлікт виникає внаслідок глибоких роздумів Довбуша про мету своєї боротьби, засоби їі досягнення, моральний обов'язок та відповідальність перед людьми і Богом. Драматург пропускає головного героя через своєрідне горнило морального очищення, готуючи до подальшої боротьби.

Несподівана з'ява в опришківському таборі запорозького козака Михайла нагадує так само несподівану 3'яву серед галицького українства молодого і енергійного Г. Хоткевича, який одразу вніс живий струмінь у національне життя Галичини на початку XX ст. Загалом уведення Г. Хоткевичем цього персонажа є уособленням соборності східної і західної частин України, розшматованих між Російською та Австро-Угорською імперіями.
Устами священика, що з'являється 3 хлопчиком серед опришків, драматург торкається моральних питань збройної боротьби опришків. За своєю динамікою та напруженістю сцена Довбуша 3 ксьондзом перегукуються зі сценою Карла Моора з патером у драмі «Розбійники» Ф. Шиллера. Однак якщо у словесному двобої ватажок розбійників Моор не лише майстерно відкидає гнівні звинувачення патера, але й завдає йому нищівної моральної поразки, то для ватажка опришків головною зброєю у двобої з ксьондзом, який, прикриваючись християнською мораллю, захищає гнобителів, були не слова, а пістоль і бартка, якою озлоблений Довбуш навіть замахнувся на священика. Тож логічно, що після моральної перемоги ксьондза над Довбушем опришки впали перед переможцем на коліна, а один 3 них, покинувши своїх товаришів, подався услід за священиком. Деморалізуюче вплинув на Довбуша також його постріл у ксьондза, що влучив у хрест, а тому вважався недобрим знаком долі.

У цій сцені драматург показав деморалізуючий вплив католицької церкви на визвольну боротьбу поневоленого народу. Знаючи, як простий люд стогне у ярмі, Довбуш не міг сприйняти слова ксьондза про те, щоб, покаявшись у своїх гріхах перед людьми і Богом, стати «тихим слугою Божим» і тоді мир вселиться в душу, милим стане «шепіт молитовний і вонь кадильна, а на устах засяє усьміх щасливого спокою» $[17,11$ зв.]. Такий «спокій», коли звідусіль чути стогін поневоленого люду, був не для Довбуша.

Після емоційно-психологічної сцени 3 ксьондзом драматург уводить позначену філософським звучанням сцену діалогу Довбуша зі старезним дідом. Довбуш, ніби сповідаючись перед дідом, розповідає йому про свої найстрашніші вчинки, про мотивацію помсти. Однак дід мудро знаходить виправдання всім вчинкам отамана, запевняючи, що гріха в них немає. Вустами старезного діда, який нагадує давньоруського волхва, промовляє не християнська філософія всепрощення, а сувора язичницька філософія наших предків, спрямована на збереження роду, племені.

Приклад благородства Довбуша зображено у сцені влаштування опришками засідки на загін смоляків під командуванням полковника Пшелуського. Довбуш свідомо не подав своїм побратимам знаку на знищення смоляків. Свій вчинок він пояснив тим, що смоляки - це набрані на службу місцеві жителі, після загибелі яких залишаться сиротами їхні діти і нікому буде їх годувати. 
У четвертій дії особливе враження справляє несподівана з'ява на храмовому святі в Криворівні опришків на чолі з Довбушем - святково вбраних і зі зброєю. Довбуш наказує товаришам не напиватись, а триматися гідно та бути готовими до всього. Г. Хоткевич майстерно виписав сцену першої зустрічі Довбуша і Дзвінки. Люди ніби чекають чогось від зустрічі цих двох молодих і красивих людей, а тому й $з$ цікавістю спостерігають за ними. Ось музики заграли «гуцулку», і Довбуш, злегка пританцьовуючи, заспівав. Приймаючи виклик Довбуша, пританцьовуючи, заспівала йому в тон Дзвінка. Так через пісню і танець, що вилились у своєрідне змагання між Дзвінкою і Довбушем, відбувається перше знайомство двох неординарних натур. У цій сцені драматург уперше зводить докупи Довбуша, Дзвінку і Дзвінчука, найтрагічніший любовний трикутник Гуцульщини, всередині якого виникає величезна напруга. Г. Хоткевич відкинув традиційний образ зрадливої Дзвінки, яка стає співучасницею вбивства Довбуша. У п’єсі Дзвінка щиро кохає Довбуша і сама стає жертвою підступності свого чоловіка.

У виставі «Довбуш» напруженість дії виникала завдяки точному влучанню на згадані ролі та майстерній грі талановитих гуцульських акторів І. Порайка (Довбуш), М. Кірикової-Ілійчук (Дзвінка), Ю. Соломійчука (Дзвінчук). І. Порайко мав не лише прекрасні зовнішні дані: «високий, широкоплечий $<\ldots>$ красиві, виразні риси обличчя, рухливий і жвавий» $[8,145]$, а й чудово співав. Його незрівнянною партнеркою була М. Кірикова-Ілійчук, красуня, яка також чудово виконувала народні пісні і навіть сама їх складала, а після блискучого виконання цієї ролі ії стали називати Дзвінкою.

Остання п'ята дія п'єси за обсягом тексту найменша, однак за сценічною напруженістю одна 3 найсильніших, оскільки саме тут зосереджена кульмінаційна сцена, а також розв'язка. Глибоким драматизмом сповнена сцена смертельного поранення Довбуша Дзвінчуком. Опришки Баюрак та Орфенюк, відчуваючи небезпеку, переконують ватажка не добиватись до хати Дзвінки. Однак Довбуш підважує колом двері й саме в цю мить лунає фатальний постріл Штефана Дзвінчука. За наказом смертельно пораненого отамана опришки підпалюють хату, а сам Довбуш, погрожуючи пістолем, наказує нікому не виходити з хати. У цій сцені поведінка Довбуша видається дещо невмотивованою. Адже, почувши з хати приглушений крик Дзвінки, отаман мав би зрозуміти, що вона стала заручницею свого чоловіка.
Сцена смертельного поранення Довбуша змальована драматургом реалістично і грунтується на документальних свідченнях та народних переказах. Власне, смертельне поранення отамана опришків $\epsilon$ найважливішим конфліктним фактом. Фінальна сцена, в якій двоє опришків садовлять пораненого Довбуша на топірці, а він співає свою останню пісню, співзвучна фіналові відомої народної пісні-балади «Ой, попід гай зелененький...».

Співаючи свою останню пісню, Довбуш наказує опришкам не йти більше «розбивати», а йти «додому газдувати», бо «людська кровця не водиця, розливати не годиться» $[17,22$ зв.]. У цій фінальній сцені, коли Довбуш «ледве чутним голосом співає $<\ldots>$ зала ридає, - зазначав Г. Хоткевич. - Ридають всі: старі баби, молоді хлопці, жінки, діти ... Бо то ж Довбуша уносять! Довбуша, такого всім рідного, такого дорогого!» $[19,561]$.

Драматична повість Г. Хоткевича «Довбуш» у 7 сценах написана Г. Хоткевичем ймовірно у 1920-х pp. i, попри певну схожість 3 однойменною драмою у 5 діях, має деякі суттєві відмінності. Так, у п'єсі відсутня сюжетна лінія кохання Довбуша і Дзвінки. Більш того, Довбуш має свою сім'ю: дружину Марту і малолітнього сина, який гине від руки гайдука. Відсутність інтриги, пов'язаної з коханням до заміжньої Дзвінки, надає сцені загибелі Довбуша, а відповідно і всій драмі, більш трагедійного звучання. Довбуш виступає в драматичній повісті не лише як народний месник, а й як народний трибун, що надає творові більшого громадянського пафосу.

Радянська цензура вороже сприйняла ідейне спрямування драми «Довбуш». В екстазі непримиренної боротьби з націоналістичними ухилами на театральному фронті заступник наркома освіти А. Хвиля 1934 р. вказував на те, що Г. Хоткевич у своїй п’єсі «Довбуш», «висвітлюючи рух опришків, ідеалізує постать ватажка опришків Олекси Довбуша і фальсифікує справжню суть руху опришків <...>. Особливе занепокоєння у цього пильного ідеолога викликала мотивація приходу запорозького козака до опришків: «Й до наших степів, i до наших порогів Дніпрових дійшов голосний гомін про славного відважного атамана Довбуша! А у нас тепер затихло щось на Україні» (виділення наше - О. Ш.) [10, 21]. Справді, у 1930-х роках, коли на повну потужність запрацювала репресивна машина, здійснюючи безприкладний геноцид українського народу, національне життя в Україні почало затихати, а тому з'ява на сцені бунтівного Довбуша, що закликає народ 
підніматися на боротьбу з гнобителями, могла б створювати загрозу комуністичному режимові.

На підставі аналізу всіх варіантів та редакцій драми Г. Хоткевича «Довбуш» можна зробити висновок, що драма «Довбуш» у 5 діях — це перша оригінальна п'єса Г. Хоткевича на гуцульську тематику, написана 1908 р. і поставлена на сцені Гуцульського театру 1911 р. Це спростовує твердження деяких дослідників щодо постановки в Гуцульському театрі драми «Довбуш» у 7 картинах, оскільки остання була написана вже в радянський час. Наявні публікації відновленої гуцульської п’єси «Довбуш» — це приклад неналежного ставлення до безцінної спадщини Г. Хоткевича, введення у науковий обіг творів, належність яких перу письменнику не доведена.

Новаторство Г. Хоткевича полягало в тому, що він, по суті, вперше в українській драматургії взяв на себе сміливість створити цикл п'єс включно 3 драмою «Довбуш», на одному 3 найбагатших архаїчних говорів української мови - гуцульському і таким чином «законсервував» для наступних поколінь мовний дивосвіт гуцулів.

Символічним є факт смертельного поранення Довбуша 23 серпня, що нині відзначається як День національного прапора, а загибелі - 24 серпня, коли була проголошена Незалежність України. I нехай між цими датами відстань у майже три століття, у здобутті цієї Незалежності є, безперечно, і заслуга народного героя Олекси Довбуша. Вона скріплена кров'ю славного лицаря, порубаного на 12 частин і порозвішуваного на палях на пострах людям. Засобами театрального мистецтва Г. Хоткевич розпочав творення своєрідної героїчної міфології Довбуша, покликаної сприяти національній самоідентифікації українців та відновленню їхньої історичної пам'яті.

\section{Джерела та література}

1. Бикова Т. В. Гуцульщина як текст в українській літературі першої третини XX ст. : дис. ... д-ра філол. наук : 10.01.01 / Бикова Тетяна Валеріївна ; НАН Украіни, Інститут літератури ім. Т. Г. Шевченка. - Київ, 2016. - $446 \mathrm{c}$.

2. Будівський П. Дещо про створення рукописної драми Гната Хоткевича «Довбуш» / Петро Будівський, Лариса Будівська // Бахмутський шлях. - 1997. № 3-4. - С. 74-76.

3. Будівський П. О. Олекса Довбуш в історії, фольклорі та літературі: проблема історичної правди / П. О. Будівський. — К. : Бланк-Сервіс, 1999. — 495 с.

4. Вдовиченко Л. Специфіка образу Довбуша в однойменній драмі Гната Хоткевича / Лариса Вдовиченко // Бахмутський шлях. - 2001. - № 1-2. C. $141-145$.
5. Денисюк I. Примітки / Іван Денисюк // Хоткевич Г.Неопубліковані гуцульські п'єси ; упоряд. : М. Дзурак та ін. - Луцьк : Терен, 2005. - С. 297-301.

6. Кирчів Р. Гуцульський театр / Р. Кирчів // Вітчизна. - 1959. - № 3. - С. 145.

7. Лист Канцелярії Головного управління у справах друку до Г. Хоткевича. 8 липня 1909 р. - Інститут літератури ім. Т. Г. Шевченка НАН України. - Відділ рукоп. фондів. - Ф. 62. - Спр. 39. - Рос.

8. Спогади про Гната Хоткевича [П. Хоткевич, Д. Кременюка, Т. Ясельської-Мельничук, Д. Минайлюка] // Стеф'юк В. Керманич Гуцульського театру. - Косів : Писаний камінь, 2000. - С. 145.

9. Стеф'юк В. Гуцульський театр і його організатор / В. Стеф'юк Керманич Гуцульського театру / В. Стеф'юк. - Косів : Писаний камінь, 2000. - 176 с.

10. Хвиля А. Завдання мистецького фронту радянської України / А. Хвиля // За марксо-ленінську критику. - Харків, 1934. - Ч. 4. - С. 10-22.

11. Хоткевич Г. «Добуш» : п'єса в 5 діях / Г. Хоткевич. - Інститут літератури ім. Т. Г. Шевченка НАН України. - Відділ рукоп. фондів. - Ф. 62. Спр. 39. - Арк. 1-64.

12. Хоткевич Г. «Добуш» : п'єса в 5 діях / Г. Хоткевич. - Санкт-Петербурзька державна театральна бібліотека. - Фонд драматичної цензури. - Інв. № 43624.

13. Хоткевич Г. «Добуш» : п’єса в 5 діях / Г. Хоткевич. - ЦДІА України у Львові. - Ф. 688. — Оп. 1. Спр. 112. - Арк. 61-109.

14. Хоткевич Г. «Добуш» : п'єса в 7 сценах / Г. Хоткевич. - Державний музей театрального, музичного та кіномистецтва України. - Відділ рукописів, архів Г. Хоткевича. - Спр. 6083. - Арк. 1-118.

15. Хоткевич Г. «Добуш» : п’єса в 7 сценах / Г. Хоткевич. - ЦДІА України у Львові. - Ф. 688. - Оп. 1. - Спр. 112. - Арк. 1-24.

16. Хоткевич Г. «Добуш» : п'єса в 7 сценах / Г. Хоткевич. - ЦДІА України у Львові. - Ф. 688. Оп. 1. Спр. 112. - Арк. 25-60.

17. Хоткевич Г. «Довбуш» : п’єса в 5 діях / Г. Хоткевич. - ЦДІА України у Львові. - Ф. 688. Оп. 1. - Спр. 111. - Арк. 1-22.

18. Хоткевич Г. Довбуш: історична драма в 5 діях / Гнат Хоткевич ; автори-упоряд. П. Будівський, Л. Будівська // Бахмутський шлях. - 1997. - № 3-4. C. $48-74$.

19. Хоткевич Г. Спогади з театральної діяльності / Г. Хоткевич // Твори : У 2 т. ; упоряд., вступ. ст. та приміт. Ф. Погребенника. - К. : Дніпро, 1966. - Т. 2. C. 552.

20. Хоткевич Г. Що робить російська цензура 3 українськими творами / Г. Хоткевич // Діло. — 1909. 12 жовт.

21. Цензор М. Алферакі про п’єсу Г.ХХоткевича «Добуш». - Російський державний історичний архів (Санкт-Петербург). — Ф. 776. - Оп. 26. - Спр. 28. Арк. 156-156 зв. - Рос.

22. Шлемко О. Поетика драматичних творів Гната Хоткевича на гуцульську тематику та їх сценічне втілення / Ольга Шлемко // Записки наукового товариства імені Шевченка. - Львів. - 2007. - T. CCLIV. С. 170-224. - (Праці театрознавчої комісії). 